\title{
Adult Hyalomma marginatum tick positive for Rickettsia aeschlimannii in Austria, October 2018
}

Georg Gerhard Duscher ${ }^{1}$, Adnan Hodžić ${ }^{1}$, Peter Hufnagl2 ${ }^{2}$, Walpurga Wille-Piazzai ${ }^{1}$, Anna-Magarita Schötta ${ }^{3}$, Mateusz Andrzej

Markowicz ${ }^{3}$, Agustín Estrada-Peña ${ }^{4}$, Gerold Stanek ${ }^{3}$, Franz Allerberger ${ }^{2}$

1. Institute of Parasitology, University of Veterinary Medicine Vienna, Austria

2. Institute for Medical Microbiology and Hygiene, Austrian Agency for Health and Food Safety Vienna, Austria

3. Institute for Hygiene and Applied Immunology, Medical University of Vienna, Austria

4. Department of Animal Pathology, Faculty of Veterinary Medicine, Zaragoza, Spain

Correspondence: Georg G. Duscher (georg.duscher@vetmeduni.ac.at)

Citation style for this article

Duscher Georg Gerhard, Hodžić Adnan, Hufnagl Peter, Wille-Piazzai Walpurga, Schötta Anna-Magarita, Markowicz Mateusz Andrzej, Estrada-Peña Agustín, Stanek Gerold, Allerberger Franz. Adult Hyalomma marginatum tick positive for Rickettsia aeschlimannii in Austria, October 2018. Euro Surveill. 2018;23(48):pii=1800595. https://doi.org/10.2807/1560-7917.ES.2018.23.48.1800595

Article submitted on 30 Oct 2018 / accepted on 29 Nov 2018 / published on 29 Nov 2018

We report on a non-indigenous adult Hyalomma marginatum tick in Austria carrying the human pathogenic Rickettsia aeschlimannii; presumably introduced as a nymph via migratory birds and completed the moulting within the same year. It was negative for Crimean-Congo haemorrhagic fever virus, but the finding of $R$. aeschlimannii represents a potential threat for humans due to its zoonotic character. Awareness of invasive tick species and carried pathogens should be improved in central and northern Europe.

Hyalomma marginatum are ticks commonly found in the Mediterranean basin, Middle East and North Africa infesting humans and animals during the prevailing tick season [1-3]. It is a known vector for several viruses such as Crimean-Congo hemorrhagic fever (CCHF), Dhori, Thogoto, West Nile, but also bacteria like Rickettsia aeschlimannii [2], which is known to be a human pathogen [4]. Here, we present the finding of R. aeschlimannii in north Austria in a living adult $H$. marginatum tick collected from a horse and discuss potential public health implications.

On 2 October 2018 a male Hyalomma marginatum tick was removed from the hind leg of a healthy 10-yearold female Haflinger horse. The stable was located in Melk district in the state of Lower Austria (Figure) and neither the horse nor the stable owner (who removed the tick) had travelled recently. After morphological determination of the tick species at the Institute of Parasitology, University of Veterinary Medicine Vienna [5], as well as molecular confirmation of the tick species [6], the tick was checked for several pathogens such as Crimean-Congo haemorrhagic fever virus (CCHFv), Rickettsia species and Babesia species. The tick was identified as $H$. marginatum and found to be positive for Rickettsia aeschlimannii; no other pathogens were detected.

\section{Investigations}

DNA and RNA were extracted according to the manufacturer's instructions with a High Pure Viral Nucleic Isolation Kit (Roche Diagnostics GmbH, Mannheim, Germany). PCRs were performed using commercial kits RealStar CCHFV RTPCR Kit 1.0 (Altona Diagnostics, Hamburg, Germany) for reverse transcription-polymerase chain reaction, or protocols targeting ITS (internal transcribed spacer) of Rickettsia sp. and $18 \mathrm{~S}$ rRNA of Piroplasmidae previously published and summarised elsewhere [7]. The positive amplicon, obtained in the Rickettsia-specific PCR, was sent for sequencing (Microsynth, Austria) and a 344 bp fragment yielded $100 \%$ identity to R. aeschlimannii (GenBank AY125016). By using an additional PCR assay that amplifies a 632 bp fragment of ompA gene of spotted fever group (SFG) Rickettsiae [8], and a 401 bp fragment of the gltA gene [9] of Rickettsia spp. confirmed this finding and yielded $100 \%$ identity to the isolate HM050286 for ompA and $100 \%$ identity to multiple $R$. aeschlimannii strains.

\section{Discussion}

In Europe, Hyalomma spp. (e.g. H. marginatum complex) are endemic in southern and eastern countries, including several countries in the Mediterranean [10], they were also detected in birds in countries where these ticks are not autochthonous e.g. the Czech Republic, Denmark, Finland, Germany, Norway, Poland, United Kingdom (UK), Slovak Republic and Sweden [10-12]. Hyalomma spp. are passively transported by migratory birds from Africa and southern Europe en route to their breeding locations in the northern hemisphere. Birds can carry the larvae and nymphs for long distances since the feeding period of these ticks may last up to 26 days $[10,12]$. Presumably favoured by warm weather conditions during summer and autumn, the dropped engorged nymphs can moult to adults and find a new host within the same year, even in areas 


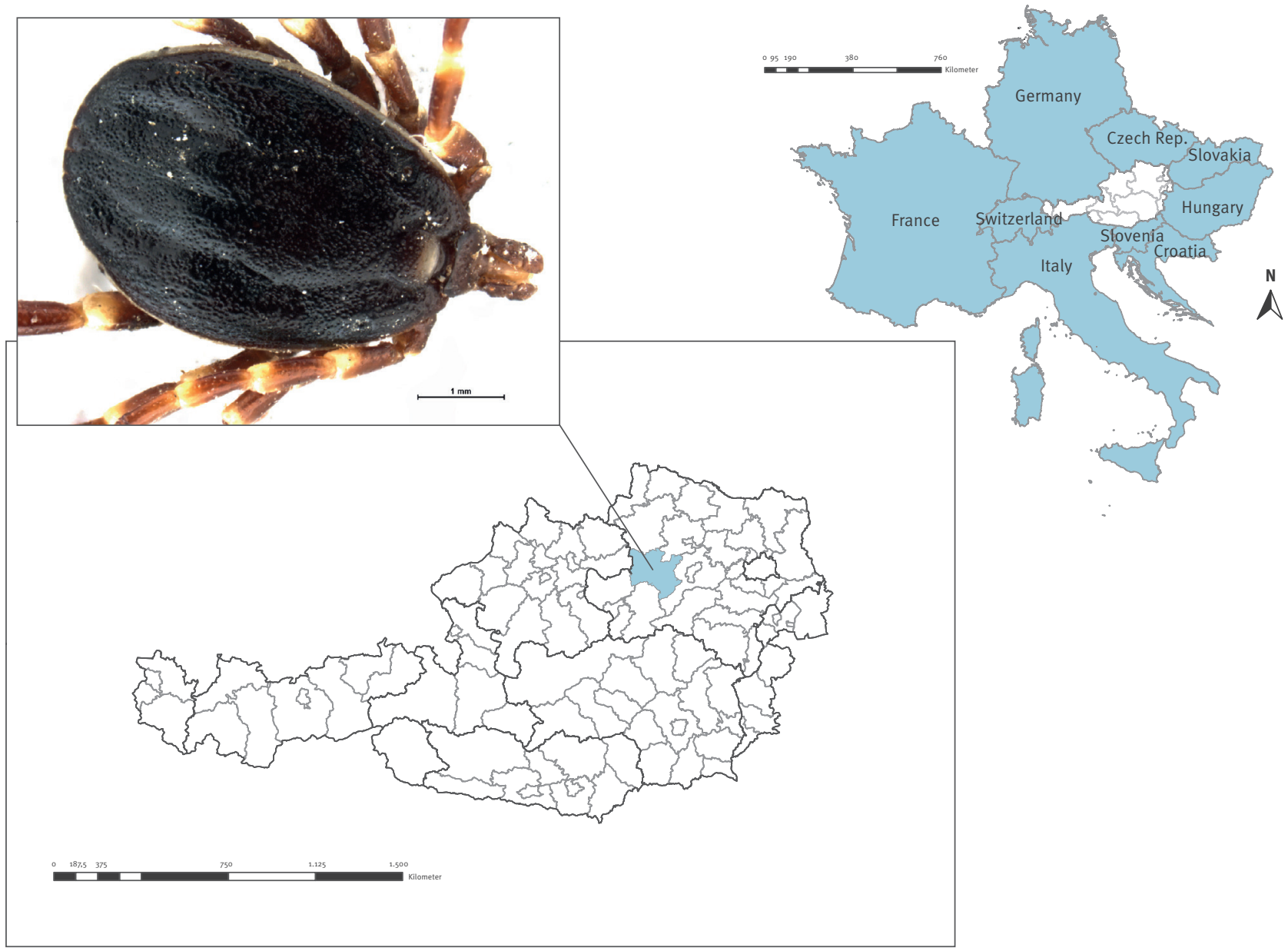

considered as environmentally unsuitable for their survival $[11,13]$. This is why in some northern areas e.g. Germany and the Netherlands $[2,13,14]$ adult ticks have been found on occasion, but they have not been able to establish permanent populations [3,13].

$R$. aeschlimannii belongs to the spotted fever group Rickettsiae [15]. In humans it causes similar symptoms to the Mediterranean spotted fever, also known as Boutonneuse fever caused by Rickettsia conorii and may be associated with liver dysfunction [16]. R. aeschlimannii was previously found in adult Dermacentor-like ticks collected from birds in Saxony-Anhalt, Germany [17], which were molecularly determined as H. marginatum. Here we described occurrence of $R$. aeschlimannii in infected adult Hyalomma spp. in another non-endemic country. It is possible that the bacteria was acquired during the blood meal from the host, however, this is unlikely as this particular pathogen was not found in any other hosts in the same geographical area.

Hyalomma ticks are also a vector for CCHFv. Cases of CCHF in Europe were historically described in
Southeastern Europe [18]. Recent detections for the first time in humans in Spain, indicate a change of pathogen occurrence and distribution, also in this case with a potential for migratory birds to act as carriers [19]. The tick investigated here was negative for CCHFv, still the finding of $R$. aeschlimannii is of great interest, given its ability to infect humans. $R$. aeschlimannii was found in 48 of 137 ticks taken from migratory birds in Italy during 2010 and 2011 [20]; this, and our more recent finding, may indicate that with favourable weather conditions there could be more imported, moulted and attached adult $H$. marginatum found carrying $R$. aeschlimannii in Central and Northern Europe.

Potential migratory bird-linked importation of Hyalomma spp. to northern European countries should be taken into account in the near future. Public health systems should prepare themselves in terms of detection of ticks, diagnostic and monitoring of pathogens transmitted by these, as well as respective treatment and control measures. On behalf of the Austrian ministry of health, the Austrian Agency for Health and Food Safety Vienna (AGES), in close cooperation with the Medical University Vienna and the University of 
Veterinary Medicine Vienna, has set up a website [21] to inform the population about potentially emerging threats associated with ticks.

\section{Acknowledgements}

We thank the stable owner of the horse for providing the tick and giving the relevant information.

\section{Conflict of interest}

None declared.

\section{Authors' contributions}

All co-authors have revised the final version and significantly contributed to the manuscript:

Georg Gerhard Duscher and Franz Allerberger coordinated the study and wrote the manuscript. Agustín Estrada-Peña confirmed the species and substantially helped with the manuscript. Adnan Hodžić, Peter Hufnagl, Walpurga WillePiazzai, Anna-Magarita Schötta performed DNA/RNA extraction and/or PCR and moleculare identification of the different pathogens. Mateusz Andrzej Markowicz and Gerold Stanek substantially revised the manuscript.

\section{References}

1. Palomar AM, Portillo A, Santibáñez P, Mazuelas D, Arizaga J, Crespo A, et al. Crimean-Congo hemorrhagic fever virus in ticks from migratory birds, Morocco. Emerg Infect Dis. 2013;19(2):260-3. https://doi.org/10.3201/eid1902.121193 PMID: 23347801

2. Oehme R, Bestehorn M, Wölfel S, Chitimia-Dobler L. Hyalomma marginatum in Tübingen, Germany. Systematic \& Applied Acarology.2017;22(1):1-6.

3. Estrada-Peña A, de la Fuente J, Latapia T, Ortega C. The impact of climate trends on a tick affecting public health: $A$ retrospective modeling approach for Hyalomma marginatum (ixodidae). PLoS One. 2015;10(5):e0125760. https://doi. org/10.1371/journal.pone.0125760 PMID: 25955315

4. Raoult D, Fournier P-E, Abboud P, Caron F. First documented human Rickettsia aeschlimannii infection. Emerg Infect Dis. 2002;8(7):748-9. https://doi.org/10.3201/eido807.010480 PMID: 12095451

5. Estrada-Peña A, Bouattour A, Camicas J-L, Walker AR. Ticks of domestic animals in the Mediterranean region: A guide to identification of species. Univ Zaragoza. 2004;131.

6. Halos L, Jamal T, Vial L, Maillard R, Suau A, Le Menach A, et al. Determination of an efficient and reliable method for DNA extraction from ticks. Vet Res. 2004;35(6):709-13. https://doi. org/10.1051/vetres:2004038 PMID: 15535960

7. Hodžić A, Mrowietz N, Cézanne R, Bruckschwaiger P, Punz $S$, Habler VE, et al. Occurrence and diversity of arthropod transmitted pathogens in red foxes (Vulpes vulpes) in western Austria, and possible vertical (transplacental) transmission of Hepatozoon canis. Parasitology. 2018;145(3):335-44. https:// doi.org/10.1017/So031182017001536 PMID: 28835291

8. Roux V, Fournier PE, Raoult D. Differentiation of spotted fever group rickettsiae by sequencing and analysis of restriction fragment length polymorphism of PCR-amplified DNA of the gene encoding the protein rOmpA. J Clin Microbiol. 1996;34(9):2058-65. PMID: 8862558

9. Labruna MB, Whitworth T, Horta MC, Bouyer DH, McBride JW, Pinter A, et al. Rickettsia species infecting Amblyomma cooperi ticks from an area in the state of São Paulo, Brazil, where Brazilian spotted fever is endemic. J Clin Microbiol. 2004;42(1):90-8. https://doi.org/10.1128/JCM.42.1.9098.2004 PMID: 14715737

10. Jameson LJ, Morgan PJ, Medlock JM, Watola G, Vaux AGC. Importation of Hyalomma marginatum, vector of CrimeanCongo haemorrhagic fever virus, into the United Kingdom by migratory birds. Ticks Tick Borne Dis. 2012;3(2):95-9. https:// doi.org/10.1016/j.ttbdis.2011.12.002 PMID: 22300969
11. Capek M, Literak I, Kocianova E, Sychra O, Najer T, Trnka A, et al. Ticks of the Hyalomma marginatum complex transported by migratory birds into Central Europe. Ticks Tick Borne Dis. 2014;5(5):489-93. https://doi.org/10.1016/j. ttbdis.2014.03.002 PMID: 24877976

12. Hasle G. Transport of ixodid ticks and tick-borne pathogens by migratory birds. Front Cell Infect Microbiol. 2013;3:48. https:// doi.org/10.3389/fcimb.2013.00048 PMID: 24058903

13. Chitimia-Dobler L, Nava S, Bestehorn M, Dobler G, Wölfel $\mathrm{S}$. First detection of Hyalomma rufipes in Germany. Ticks Tick Borne Dis. 2016;7(6):1135-8. https://doi.org/10.1016/j. ttbdis.2016.08.008 PMID: 27567111

14. Nijhof AM, Bodaan C, Postigo M, Nieuwenhuijs H, Opsteegh $M$, Franssen $L$, et al. Ticks and associated pathogens collected from domestic animals in the Netherlands. Vector Borne Zoonotic Dis. 2007;7(4):585-95. https://doi.org/10.1089/ vbz.2007.0130 PMID: 17979540

15. Beati L, Meskini M, Thiers B, Raoult D. Rickettsia aeschlimannii sp. nov., a new spotted fever group rickettsia associated with Hyalomma marginatum ticks. Int J Syst Bacteriol. 1997;47(2):548-54. https://doi.org/10.1099/00207713-47-2548 PMID: 9103647

16. Tosoni A, Mirijello A, Ciervo A, Mancini F, Rezza G, Damiano F, et al. Internal Medicine Sepsis Study Group. Human Rickettsia aeschlimannii infection: first case with acute hepatitis and review of the literature. Eur Rev Med Pharmacol Sci. 2016;20(12):2630-3. PMID: 27383315

17. Rumer L, Graser E, Hillebrand T, Talaska T, Dautel H, Mediannikov O, et al. Rickettsia aeschlimannii in Hyalomma marginatum ticks, Germany. Emerg Infect Dis. 2011;17(2):325-6. https://doi.org/10.3201/eid1702.100308 PMID: 21291625

18. Hornok S, Horváth G. First report of adult Hyalomma marginatum rufipes (vector of Crimean-Congo haemorrhagic fever virus) on cattle under a continental climate in Hungary. Parasit Vectors. 2012;5(1):170. https://doi.org/10.1186/17563305-5-170 PMID: 22889105

19. Negredo A, de la Calle-Prieto F, Palencia-Herrejón E, Mora-Rillo M, Astray-Mochales J, Sánchez-Seco MP, et al. Crimean Congo Hemorrhagic Fever@Madrid Working Group. Autochthonous Crimean-Congo Hemorrhagic Fever in Spain. N Engl J Med. 2017;377(2):154-61. https://doi.org/10.1056/NEJMoa1615162 PMID: 28700843

20. Toma L, Mancini F, Di Luca M, Cecere JG, Bianchi R, Khoury $C$, et al. Detection of microbial agents in ticks collected from migratory birds in central Italy. Vector Borne Zoonotic Dis. 2014;14(3):199-205. https://doi.org/10.1089/vbz.2013.1458 PMID: 24576218

21. Vienna: Austrian Agency for Health and Food Safety (AGES). Vienna: AGES; 2018 [Accessed 27 Nov 2018]. Available from www.ages.at/zecken

\section{License and copyright}

This is an open-access article distributed under the terms of the Creative Commons Attribution (CC BY 4.0) Licence. You may share and adapt the material, but must give appropriate credit to the source, provide a link to the licence, and indicate if changes were made.

This article is copyright of the authors or their affiliated institutions, 2018. 